\title{
Lipopolysaccharide as Receptor for Rhizobium Phage 1P
}

\author{
By ELŻBIETA ZAJAC, R. RUSSA AND Z. LORKIEWICZ \\ Institute of Microbiology and Biochemistry, M. Curie-Sklodowska University, \\ 20-033 Lublin, Poland
}

(Received 6 February 1975; revised II June 1975)

\section{INTRODUCTION}

There are only a few papers concerning the sites of phage adsorption in Rhizobium. Barnet \& Vincent (1970) suggested that the receptor site for phages 7, 7cr, and 8 was associated with the somatic antigen of Rhizobium. Atkins \& Hayes (1972) found alterations in lipopolysaccharide (LPS) and lipoprotein (LP) of Rhizobium trifolii mutants that adsorbed phage poorly.

To elucidate the attachment site of phage IP to Rhizobium, we studied cell walls and their LPS preparations as phage receptors.

\section{METHODS}

Bacterial and phage strains. Rhizobium trifolii strains 24SM, HR, I5, 24AR and XSM were used in these experiments. Mutants HR and I5, resistant to phage IP, were derived from 24SM. The former was obtained by u.v. treatment, whereas the latter was a spontaneous mutant isolated by selection with phage IP. Phage IP propagated on $R$. trifolii 24SM was employed in assays of receptor activity of cell walls and LPS. It does not require divalent ions for its attachment to bacteria (Staniewski, 1968).

Media. Bacteria were grown in medium 4, containing (g/l glass-distilled water): $\mathrm{K}_{2} \mathrm{HPO}_{4}$, $3.6 ; \mathrm{MgSO}_{4} .7 \mathrm{H}_{2} \mathrm{O}, 0.5 ; \mathrm{NaCl}, 0.5$; ferric ammonium citrate, 0.05 ; Casamino acids, 3.0 ; glucose, $10 \cdot 0 ; \mathrm{pH} 7 \cdot 6$.

Preparation of cell walls, LPS and polysaccharides (PS). Rhizobium trifolii cell walls were prepared by a slight modification of the procedure of Roberson \& Schwab (1960). LPS was prepared according to Westphal \& Jann (1965). LPS of strain 24SM, instead of being centrifuged, was fractionated on a Sepharose $2 \mathrm{~B}$ column and eluted with $0.0 \mathrm{I} \mathrm{M}-\mathrm{NH}_{4} \mathrm{HCO}_{3}$ (Romanowska, 1970). PS was prepared according to Berst et al. (1969).

Deacetylation of cell walls and LPS by $\mathrm{NaOH}$ and $\mathrm{NH}_{4} \mathrm{OH}$. Cell walls and LPS $(5 \mathrm{mg} / \mathrm{ml})$ were treated with $0.1 \mathrm{M}-\mathrm{NaOH}$ or $2.5 \mathrm{M}-\mathrm{NH}_{4} \mathrm{OH}$ at $37^{\circ} \mathrm{C}$ for $\mathrm{I} \mathrm{h}$. The mixture was chilled, neutralized with $0 \cdot \mathrm{I} \mathrm{M}-\mathrm{HCl}$ and centrifuged. The pellet was washed three times and lyophilized.

LPS oxidation with $\mathrm{NaIO}_{4}$. LPS was oxidized according to a modification of the procedure of Foster, Davies \& Crumpton (1958). One $\mathrm{ml}$ of LPS (10 mg/ml) was mixed with $0.5 \mathrm{ml}$ of $2 \%(\mathrm{w} / \mathrm{v}) \mathrm{NaIO}_{4}$ and incubated at $20^{\circ} \mathrm{C}$ for $\mathrm{I} 2 \mathrm{~min}$. Excess $\mathrm{NaIO}_{4}$ was decomposed by ethylene glycol. After $20 \mathrm{~min}, 0.5 \mathrm{ml}$ of $\mathrm{I} \%$ (w/v) $\mathrm{NaBH}_{4}$ was added. Excess $\mathrm{NaBH}_{4}$ was then decomposed by acetic acid $(0.2 \mathrm{ml})$ and dialysed overnight against distilled water.

Inactivation of phage I $P$. Cell walls of LPS, at a concentration of $\mathrm{I}$ to $50 \mu \mathrm{g} / \mathrm{ml}$ in tris$\mathrm{HCl}$ buffer $\mathrm{pH} 7 \cdot 4$, were mixed with an equal volume of phage IP containing $6 \times 10^{3}$ plaque forming units (p.f.u.). The mixture was incubated at $37^{\circ} \mathrm{C}$ without shaking. At intervals, samples were removed and tested for phage survival using $R$. trifolii $24 \mathrm{SM}$ as the indicator culture. 
Table I. Composition of sugars in LPS preparations

\begin{tabular}{|c|c|c|c|c|c|}
\hline \multirow[b]{2}{*}{ Sugar } & \multirow{2}{*}{$\begin{array}{l}\text { Retention } \\
\text { times }\end{array}$} & \multicolumn{4}{|c|}{ Content of sugars ( $\mathrm{mol} \mathrm{\%}$ ) } \\
\hline & & $24 \mathrm{SM}$ & XsM & HR & 15 \\
\hline Rhamnose & 0.18 & - & $8 \cdot 0$ & - & - \\
\hline Fucose & 0.195 & 0.8 & $-\ldots$ & - & - \\
\hline Ribose & 0.27 & - & - & $3 \cdot 0$ & 0.3 \\
\hline Arabinose & 0.3 & - & 0.5 & - & Trace \\
\hline Mannose & 0.75 & $14 \cdot 3$ & $\mathbf{2 \cdot 2}$ & $35 \cdot 0$ & $16 \cdot 2$ \\
\hline Galactose & 0.86 & 6.0 & $2 \cdot 6$ & $33 \cdot 5$ & $12 \cdot 4$ \\
\hline Glucose & $1 \cdot 00$ & $1 \cdot 5$ & $86 \cdot 2$ & $7 \cdot 0$ & $4 \cdot 8$ \\
\hline$X_{1}$ & I.27 & 2.8 & - & - & - \\
\hline $\mathrm{X}_{2}$ & I.47 & $3 \cdot 1$ & - & - & $2 \cdot 6$ \\
\hline $\mathrm{X}_{3}$ & $1 \cdot 77$ & Trace & - & - & I.5 \\
\hline Heptose I & 1.97 & $10 \cdot 0$ & - & - & $5 \cdot 0$ \\
\hline Heptose II & $2 \cdot 32$ & $62 \cdot 3$ & - & $22 \cdot 0$ & $57 \cdot 2$ \\
\hline
\end{tabular}

Retention times are expressed relative to that of glucose. Results are expressed as percentages of the total sugars. Heptose I, D-glycero-D-mannoheptose; heptose II, L-glycero-D-mannoheptose; compounds $\mathbf{X}_{\mathbf{1}}, \mathbf{X}_{\mathbf{2}}$ and $X_{3}$ were unidentified.

\section{RESULTS AND DISCUSSION}

Preliminary studies showed that both cell walls and LPS from several phage-sensitive strains effectively inactivated phage $I P$, while those from the two phage-resistant mutants inactivated the phage only slightly. Thus, approximately $0.1 \mu \mathrm{g}$ LPS from strain $24 \mathrm{SM}$ inactivated $50 \%$ of the p.f.u. within I $h$, while LPS from the two mutants inactivated less than $10 \%$ during the same period.

The effect of various modifications of cell walls and LPS on their ability to inactivate phage was determined. Deacetylation of cell walls and LPS caused a loss of phage-inactivating ability. Untreated cell walls or LPS from strain 24SM inactivated 93 to $96 \%$ of p.f.u. within $30 \mathrm{~min}$, while cell walls and LPS deacetylated by treatment with $2.5 \mathrm{M}-\mathrm{NH}_{4} \mathrm{OH}$ or $0.1 \mathrm{M}-$ $\mathrm{NaOH}$ inactivated only 9 to $16 \%$ and $\mathrm{I}$ to $8 \%$ of p.f.u., respectively. The need for acetyl groups for effective phage adsorption has been noted in other species. For example, the capacity of Staphylococcus aureus cells walls to inactivate phage 52A was lost by removing $O$-acetyl groups (Shaw \& Chatterjee, 197I). Adsorption of Vi phage onto bacterial surfaces results in the formation of a complex phage-bound $\mathrm{Vi}$-polysaccharide deacetylase with $\mathrm{Vi}$ polysaccharide, leading to deacetylation. Phage-treated Vi polysaccharide regains receptor activity after acetylation (Taylor, I966).

Oxidation of LPS also caused a significant decrease in phage inactivation. LPS from strain $24 \mathrm{SM}$, oxidized with $2 \%(\mathrm{w} / \mathrm{v}) \mathrm{NaIO}_{4}$ and then reduced with $\mathrm{I} \%(\mathrm{w} / \mathrm{v}) \mathrm{NaBH}_{4}$, inactivated only $5 \%$ of the phage.

Intact LPS was required for phage inactivation. Polysaccharide obtained from the LPS of strain $24 \mathrm{SM}$ after hydrolysis with acetic acid at $100{ }^{\circ} \mathrm{C}$ failed to inactivate phage IP. The function of the lipid may be to stabilize the configuration of the attachment site (Lindberg, 1973).

The molar ratios of neutral sugars in the LPS isolated from strains 24SM, XSM, HR and I5 were determined (Table I). A high content of L-glycero-D-mannoheptose (more than $50 \%$ of the molar ratio) was characteristic of the neutral sugars of LPS preparations from strains 24 SM and 15 but was missing from strain XSM, a strain whose LPS inactivates phage IP poorly. This suggested that heptoses might form part of the phage receptor, and was consistent with the effects of oxidation on phage inactivation since this treatment degrades L-glycero-D- 
mannoheptose (Foster et al. 1958). However, the LPS of the phage-resistant mutant, strain I5,'contained a large amount of L-glycero-D-mannoheptose but failed to inactivate phage IP.

This research was supported by the Polish Academy of Sciences within project 09.3.I.

\section{REFERENCES}

Atkins, G. J. \& HaYes, A. H. (1972). Surface changes in a strain of Rhizobium trifolii on mutation to bacteriophage resistance. Journal of General Microbiology 73, 273-278.

BARNET, Y. M. \& VINCENT, J. M. (1970). Lysogenic conversion of Rhizobium trifolii. Journal of General Microbiology 6r, 319-325.

Berst, M., Hellerqvist, C. G., Lindberg, B., Lüderitz, O., Svensson, S. \& WestPhal, O. (I969). Structural investigations on $\mathrm{T}_{1}$ lipopolysaccharides. European Journal of Biochemistry Ir, 353-359.

Foster, A. B., Davies, D. A. L. \& Crumpton, M. J. (1958). Action of periodate on some polysaccharides containing aldoheptose sugars. Nature, London $\mathbf{8 1}$, 412-413.

LINDBERG, A. A. (1973). Bacteriophage receptors. Annual Review of Microbiology 27, 205-24I.

Roberson, B. S. \& SCHWAB, J. H. (1960). Studies on preparation of bacterial cell walls and criteria of their homogeneity. Biochimica et biophysica acta 44, 436-444.

Romanowska, E. (1970). Sepharose gel filtration method of purification of lipopolysaccharides. Analytical Biochemistry 33, 383-389.

Shaw, D. R. D. \& ChATTERJEe, A. N. (1971). $O$-acetyl groups as a component of the bacteriophage receptor on Staphylococcus aureus cell walls. Journal of Bacteriology 108, 584-585.

STANIEWSkI, R. (1968). Typing of Rhizobium by phages. Canadian Journal of Microbiology r6, 1003-1009.

TAYLOR, K. (1966). Physical and chemical changes of Vi-polysaccharide due to Vi-phage II action. Acta biochimica polonica I3, 97-106.

WeSTPHAL, O. \& JANN, K. (1965). Bacterial lipopolysaccharides. Extraction with phenol-water and further applications of the procedure. In Methods in Carbohydrate Chemistry, vol. 5, pp. 83-91. Edited by R. L. Whistler. London: Academic Press. 